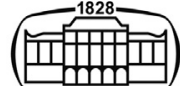

AKADÉMIAI KIADÓ

UNIVERSITY of DEBRECEN

\section{International Review of Applied Sciences and Engineering}

13 (2022) 1, 1-10

DOI:

10.1556/1848.2021.00278

(c) 2021 The Author(s)

\title{
Information Technology deployment in Human Resource Management: A case study in deprived regions
}

\author{
Peter Akpamah $^{1 *} \odot$ and Andrea Matkó ${ }^{2}$ \\ ${ }^{1}$ BOTECH/UCC, Ghana, Africa \\ ${ }^{2}$ Department of Management and Enterprises, University of Debrecen, Debrecen, Hungary
}

Received: March 22, 2021 • Accepted: April 30, 2021

Published online: July 2, 2021

\section{CASE STUDY}

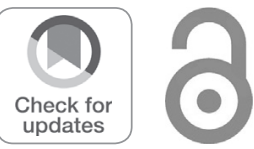

* Corresponding author.

E-mail: akpamah.peter@yahoo.com

\begin{abstract}
In recent years, managers of both private and public organizations in developing countries have been struggling to double production and improve service delivery in their organizations. Successful organizations in the western world were, however, identified with the use of Information Technology (IT). The paper examined the magnitude of IT and its application in human resource management. Four organizations from private and public sectors were selected from all. Two organizations from each sector, members of staff, Human Resource (HR) professionals and managers of these organizations were targeted. A structured questionnaire was used to collect data from the staff and unstructured interviews were designed to gather data from the HR practitioners and managers of these organizations. A statistical package for social sciences (SPSS) was used to analyse the data. In general, about $76.9 \%$ of the participants said that IT application in HR functions enhances organizational productivity. The selected organizations could boast of basic IT facilities, but their numerical strength still remains a challenge especially among organizations in the public sector. Organizations in both sectors must invest more in IT and its related accessories as a means of solving problem of inadequacy. Internet connectivity and company website were lacking in some organizations across both sectors and should be considered so as to improve upon the human resource functions and quality service delivery in the deprived regions of Ghana. Staff motivation, wage and salaries, strategic management and organizational leadership were mentioned as factors when put together with IT would augment productivity in any given economy.
\end{abstract}

\section{KEYWORDS}

Information Technology, deployment, organizations, Human Resource Management

\section{INTRODUCTION}

An organization is a consciously coordinated unit formed by groups of persons working towards the achievement of specific objectives [1]. An organization can also be defined as the privileges and responsibilities of an individual to contribute to the attainment of organizational goal devoid of conflict [2]. The Ghana Information and Communication Technology (ICT) for Accelerated Development Policy indicates that the success of IT in an organization depends on how the country would be capable of developing and harnessing its human resource [3]. IT initiates and redefines organizational culture, and maintains socio-economic development towards an information and knowledge economy [4]. Computerization has been identified among other management strategies as an effective tool in the management of various sectors in any given nation [5]. The concept of management information systems originated in the 1960s with a focus on the computerization of clerical and record-keeping task [6]. Technology has performed beyond the perception of its being business problem solving tool [7].

Technology literacy involves being able to use computers to communicate, solve problems, collect, organize and share information [8]. IT is useful in developing decision 
alternatives, gathering and analysing information required for evaluating employees' performance [9]. The ability to access internet and wireless communications is no longer a luxury but rather a necessity for economic growth and development [10]. The world today is described as a global village as the management of human capital in organizations is done with the aid of Information Technology [11]. There is an increasing demand for IT to improve upon socioeconomic development fortunes of nations [12]. Both natural and acquired resources may not be fully utilized if organizations do not have enough human capital, sense of responsibility and technical know-how to apply for a national development [13]. With the development of technology and innovative skills, the new global economy is fuelled by brain power and intellectual capitalism [14]. The acceptance and practice of IT is no longer for only the computation of figures and record-keeping, but business innovative tool for effective management [15]. Most organizations in deprived regions could not use IT which is mainly due to not having IT facilities or professionals to control IT systems and implementation in their areas of operation [16]. The consequence of adopting or not adopting IT in HR management is obvious as Biswas [17] states that not less than $54 \%$ of all employees will require significant training and development in IT to enable them be efficient in their current jobs.

However, not much attention has been given to the spatial dimension with respect to the distribution of IT facilities especially in the deprived regions [15]. Africa is still at the bottom in IT knowledge and its applications [18]. Even organizations that deployed IT still adopt the traditional approach to file where systems tend to grow independently [2]. Organizations running by the principles of the traditional model do not only cause delays in document processing, but also cause economic burden leading to inefficiencies in organizations and poor quality in service delivery [19]. Therefore, it merits exploring the availability and application of Information Technology (IT) in HR functions among some organizations in Northern Ghana. This paper seeks to answer the question; "What is the magnitude of IT for human resource management in organizations operating within the deprived regions of Ghana?" The main objective of the study finds out if the application of IT in Human Resource Management (HRM) functions had an influence on quality service delivery in organizations.

\subsection{Theoretical background}

Bawany [20] categorises industrial revolutions as the transport and mechanical production revolution of the late 18th century, the mass production revolution of the late 19th century, and the computer revolution of the 1960s, this explains why technology has become the engine of growth for so many years. Since 1969, IT has been developed into digital technology and advanced beyond the 1980s to become the 4th digital revolution where Internet connectivity is globally experienced [21]. Information Technology was introduced to trade and industry in the 1970s where procurement of raw material was done through electronic system known as Material Requirements Planning (MRP) [11].

The term Information Technology became popular in business organizations in 1981 to describe the equipment and systems introduced to create, store and distribute information [6]. IT is the fastest provider of information as and when decision is needed to be taken by management for the well-being of the organization [2]. Management acceptance to use IT greatly depends on employees' ability to learn new skills for self-development and organizational performance [22]. Human Resource Management (HRM) is a multi-disciplinary organizational function which derives its theories and ideas from various fields of study [23]. The application of IT in Human Resource Management leads to effective cost control management and timely response to the needs of employees and customers' demand [24]. The human resource management is an important aspect needed in administration for effective and efficient utilization of resources [13]. HRM requires the involvement of Information Technology (IT) as a strategy and coherent approach to the management of organisation's most valued assets, the people $[25,26]$. In this study, "Information Technology (IT)" and "Information and Communication Technology (ICT)" are used as synonyms. These concepts when used, are commonly referred to computers, the Internet, digital network/devices and various digital applications that are used with these tools [27].

\subsection{Human Resource Management via Information Technology}

Information Technology (IT) has ushered the World into post-industrial age of automation in which the computer enables man to operate, compute, control, repair and maintain other machines [28]. The use of IT in the management of employees began in the 18th century where machinery was introduced and workers anticipated its effect on their jobs [29]. IT alters the rules of competition among both national and international organizations [30]. Advance in technology is associated with a high rate of change that redefines features of modern organizations [31]. Information Technology (IT) is a tool for improving the socio-economic development of nations and well-being of the individual [11-32]. The availability of modern computers, peripherals, networking and resources within an increasingly diverse range of technologies is an essential part of an institutional progress in the 21st century [33]. Key corporate assets such as intellectual property, core competencies, finance and human resource are managed through digital means [2]. With IT in HR functions, the organization gets experience in the electronic-Human Resource Management (e-HRM) in addition to the financial gains [34].

The practice of IT enables an organization to align innovative skills with other resources that can mitigate external factors in order to gain competitive advantage over 
its competitors [5]. IT improves the Human Resource Management ability for a sustainable management of knowledge and asset for organizational growth and socioeconomic development of the employee [25-35]. Technology has become a very essential tool for competition in the 21 st century human resource management irrespective of the nature or size of an organization [30]. How Technology is infused into human resource functions determines the consistency of quality delivering of service to retain customers [26]. The speed, efficiency and cost-effectiveness associated with technological advancement are the main reasons for which technology is strongly demanded by human resource professionals and administrators for effective performance and cost containment [36]. IT is reliable and easily responsive to Human Resource (HR) functions [5]. The significance of IT in human resource management is so marvellous that it cannot be ignored by any nation, because IT is a platform where people seek information about their fields of interest, expertise, advertise their talents and works [37]. The opportunities in IT can reduce cost of production, and that may increase general productivity of the organization [38].

The Information Technology (IT) has the potentials of improving upon the human resource management functions which include attracting, retaining and motivating employees [39]. A survey conducted by Tzafrir, Gedaliahu, Yehuda and Shimon, [40] shows that IT enhances employees' development, creates a sense of commitment and faith in management. IT computerizes the payroll processing, transactional activities and speeds up administrative processes [39]. The employment of IT in an organization has enormous benefits for various units or departments, most especially, the HR department [41]. IT is a perfect tool in the Human Resource (HR) unit that establishes and maintains accurate databases for staff development programmes, retirement preparation courses and designed manpower needs [6]. Decision Support System (DSS) and Expert System (ES) are IT tools for a very effective decision making in today's organizational setting [42].

\subsection{The conceptual framework}

A conceptual framework was developed to discuss Information Technology on human resource management. Information Technology is divided into two major types namely: IT for converting or processing data into information such as calculators, typewriters and computers, and IT for communicating data and information from one place to another which includes telegraph, telephone and computer networks [42]. The United Nations Economic and Social Commission for Asia and the Pacific (UNESCAP) defined IT as technologies people use to share, distribute, gather information, and to communicate through computer networks [22]. In this study, IT is viewed as a set of tools that can be used to process, avail and access information and communication services or products. The services and products may include hardware and software, Internet, telephones/mobile phones, typewriter, photocopy machines, radios, televisions, hydraulic machines used in industries among others.

The key areas in the study include IT availability, opportunities and practice. Availability seeks to find out the presence of IT resources in the selected organizations for the human resource management unit. The opportunities and practice explain the level at which human resource practitioners use IT to enhance their operations or daily activities. It is significant to emphasize that the study is not basically about evaluating the performance and the progress made by these selected organizations towards the realization of their set of targets, but on the examination of a possible link between the deployment and exploitation of IT within the human resource unit in relation to the organizational achievement. It is also to illustrate the possible impact that IT could have as an enabling tool for socio-economic development in an organization. Information, knowledge and technology are increasingly becoming the key drivers for socio-economic development world-wide and IT is dramatically changing our way of life [7]. Figure 1 shows the availability and utilization of IT within the Human Resource (HR) functions. It has explained that the use of IT by the human resource management unit in any given organizations provides opportunity for quality product and service delivery. Also, IT facilitates easy interaction within and beyond the organizational setting which could lead to prudent management and high productivity.

The individual knowledge in information and communication technology and private ownership of ICT facilities within the workforce in organizations can also bring about easy access to information as shown in Fig. 1. The model presents the relationship between availability of IT and ability of personnel to make use of it for the maximum gain. The approval of Information Technology (IT) in Human Resource Management (HRM) unit is greatly influenced by the availability of IT systems and how they are used to the advantage of HR practitioners. A country that encourages and provides adequate IT for the human resource (HR) departments has the opportunity of attracting foreign investors to speed up economic growth and development [43].

\section{METHODOLOGY}

Both qualitative and quantitative methods were used in the study. With the mixed method through in-depth interviews and questionnaires respectively, assessing the availability and practice of IT in deprived regions of Ghana was successfully made. Data collected for the study were taken from both public and private organizations with two from each sector. The data were in two categories, primary and secondary data. The primary data were obtained from HR professionals, members from top management and employees in these selected organizations. The secondary data were acquired through libraries, internet and literature earlier authored by others in textbooks and journals. The 


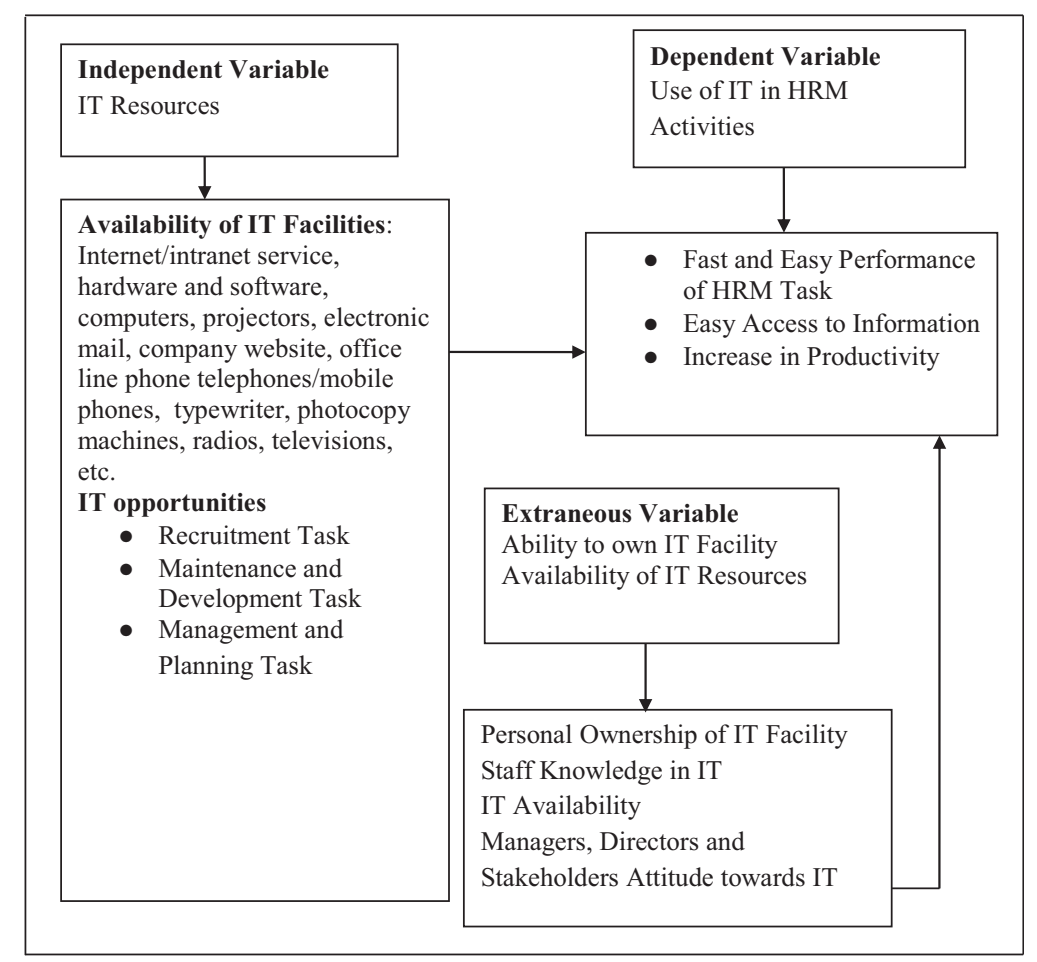

Fig. 1. The Information Technology availability model, adopted and modified [33]

questionnaires contained both closed-ended and openended items. The Opira [33] questionnaire was adopted and modified to suit the study. The questionnaires were administered directly to a target population of one hundred and four (104). The questionnaires had forty (40) items; four open-ended items and thirty-six closed-ended items. Both probability and non-probability sampling were used in this study. Purposive sampling was deployed to select Human Resource Professionals, since HR plays a key role in organizational performance. Random sampling was adopted in selecting employees, whilst non-random, that is the quota sampling was used to select a member from the top management team of each organization. They were not selected by chance, but because they occupied certain positions at the time of study.

\subsection{Presentation and analysis of data}

Data processing and analysis started from the time of the recording of interviews. This was required to verify, translate, and transcribe if necessary, code and thereafter, the analysis. The recorded audio recordings were reviewed immediately after the event in order to authenticate the quality of the recording and to follow up the interview if required. After the data collection, a thorough check was done on the questionnaires proceeding coding and entering into software version 22.0 of the Statistical Package for Social Sciences (SPSS). Microsoft Excel, among others were used for the analysis of data and with broad description of the findings presented through percentages, frequencies, graphs, mean and standard deviation.

\section{DISCUSSIONS AND CONCLUSIONS}

\subsection{Socio-demographic characteristics of the respondents}

The sex distribution of the respondents indicates that the male respondents were $60.6 \%$, while the female respondents were $39.4 \%$. The results reveal that there are more males employed in the various organizations or sectors than the females in the study area as showed in Table 1.

The data in Table 2 show that majority of the respondents were between the age brackets of 36-45 representing 52.9\%. The least representation of the respondents' age group was $5.8 \%$ with ages ranging from 56 to 60 . The

Table 1. Sex distribution of the respondents

\begin{tabular}{lcc}
\hline Sex & Frequency & Percentage \\
\hline Male & 63 & 60.6 \\
Female & 41 & 39.4 \\
Total & $\mathbf{1 0 4}$ & $\mathbf{1 0 0}$ \\
\hline
\end{tabular}

Table 2. Age groupings of the respondents

\begin{tabular}{lcc}
\hline Age in years & Frequency & Percentage \\
\hline $18-35$ & 28 & 26.9 \\
$36-45$ & 55 & 52.9 \\
$46-55$ & 15 & 14.4 \\
$56-60$ & 6 & 5.8 \\
Total & $\mathbf{1 0 4}$ & $\mathbf{1 0 0}$ \\
\hline
\end{tabular}


remaining $41.3 \%$ were ages ranging from 18 to 35 and 46 to 55 . The results suggest that about $80 \%$ of the respondents were within active working age range in these organizations. The data in Fig. 2 demonstrate the level of education of the respondents involved in the study.

Data in Fig. 2 show that more than half of the respondents involved in the study attained higher education at the tertiary level representing $54.8 \%$, followed by respondents with A 'Level/BCE/O' Level Certificates with $29.8 \%$. The remaining $15.4 \%$ were holders of SSCE/Middle School Certificates and those with no formal education that is $12.5 \%$ and $2.9 \%$ respectively. This shows that majority of the study participants attained higher education by which the implementation of IT in these organizations can receive a maximum attention of the employee.

The results on the findings of the mean year of schooling of the respondents in the study area were presented in $\mathrm{Ta}$ ble 3. The data show that the mean year of schooling for the respondents is 15.8 with a standard deviation of 3.2 for the public sector, whereas the private sector had a mean of 16.6 with a standard deviation of 1.9. This is an indication that the private organizations employed applicants with a higher level of qualification than that of the public sector. Collectively, the study shows a T-test of 0.35 years the employees spend in school. The results show no statistically significant difference in the number of years spent by staff from either sector in schooling.

\subsection{Assessing individual ownership or usage of IT facilities}

For the assessment of individual worker's ownership and practice of IT facilities, Fig. 3 shows that $99 \%$ of respondents use mobile phones indicating nearly $100 \%$ of the respondents were mobile phones users in the study area. The results confirm Wachira [10] findings in which the 21st century ICTs in use included internet, mobile and wireless communications as these facilities control and monitor

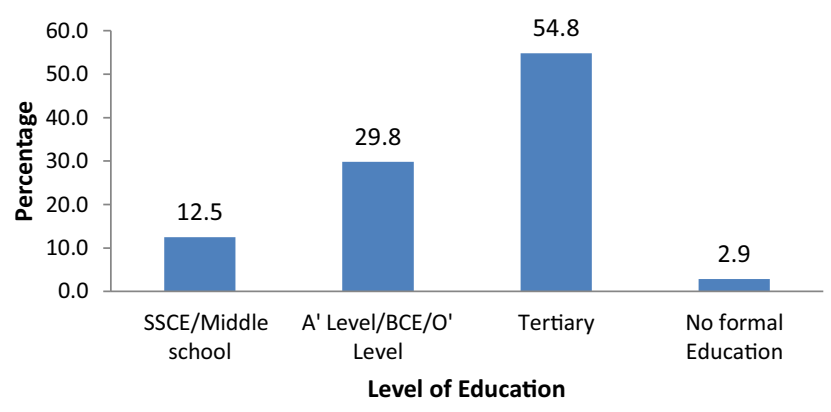

Fig. 2. Educational background of the respondents

Table 3. The respondents' years in schooling

\begin{tabular}{lcccc}
\hline Sector & Frequency & Mean & Std. deviation & T-test \\
\hline Government & 87 & 15.8 & 3.2 & 0.35 \\
Private/NGO & 17 & 16.6 & 1.9 & \\
Total & $\mathbf{1 0 4}$ & & & \\
\hline
\end{tabular}

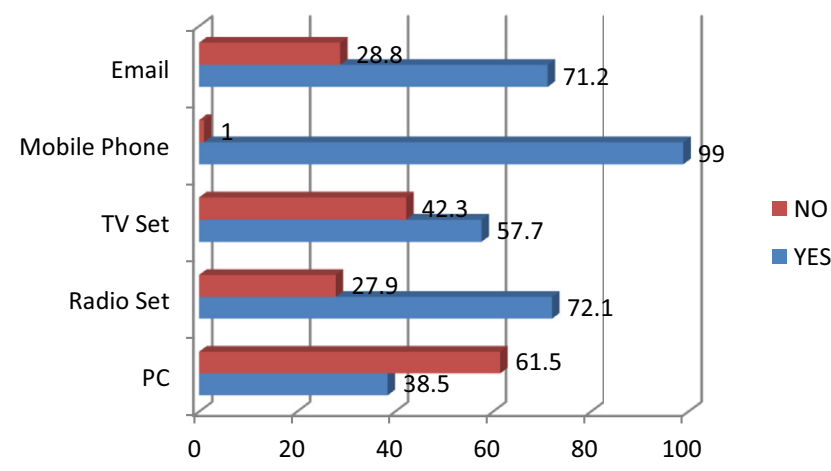

Fig. 3. Respondents' ownership of IT facilities

different appliances and implementation in a comprehensive manner in organizations. The Radio set was found second higher ICT facility in use by the study organizations with $72.1 \%$ of the respondents, followed by Electronic mail with $71.2 \%$ of the respondents. The study revealed $61.5 \%$ and $42.3 \%$ of the respondents do not use Computer and Television set respectively at the time of study as demonstrated in Fig. 3. The results are evident of a need of Information and Communication Technology in industries and organizations to enable effective and efficient execution of the HR and administrative functions in any given organizational setting.

\subsection{Availability of ICT facilities in organizations}

Table 4 presents data on available IT facilities in organizations. This is presented in percentages including the sectors participated in the study whereas Fig. 4 highlights only the IT tools involved and their corresponding percentages. In this case, both Fig. 4 and Table 4 are very necessary for pictorial view. Therefore, regarding the use of computer as one of the ICT facilities in various organisations, Table 4 shows that $99 \%$ of the respondents responded in affirmative whiles the remaining $1 \%$ responded in the negative. It is obviously clear that all the organizations that took part in the study use computers in the performance of their duties. Table 4 shows that Video Conference Centres were very few in the study area as they represented by only $15.4 \%$ of the total respondents with $93.1 \%$ of the respondents from the public sector acknowledged the absence of these facilities. About $94.1 \%$ of the respondents from the private organizations responded that Video Conference centres were available. The results in Table 4 reveal that in total, radio set has a poor representation especially in the public sector organizations as its availability was supported by only $27.9 \%$ of respondents. Little over $86 \%$ of the respondents from the public sector said it was not available, while a $100 \%$ of the respondents in the private organizations confirmed its availability. The statistics concerning the availability of IT key devices in these organizations is discouraging and the results are in contrast with literature where it is stated that IT has become a global knowledge such that no nation, organization and department/unit would in recent times be denied of its applications. 
Table 4. Availability of IT facilities in organizations presented in percentage

\begin{tabular}{|c|c|c|c|c|c|}
\hline ICT Facilities & Sector & $\begin{array}{c}\text { Available } \\
\%\end{array}$ & $\begin{array}{c}\text { Not } \\
\text { available } \\
\%\end{array}$ & $\begin{array}{c}\text { No } \\
\text { idea } \\
\%\end{array}$ & $\begin{array}{c}\text { Total } \\
\%\end{array}$ \\
\hline \multirow[t]{2}{*}{ Computer } & Gov. & 98.8 & 1.2 & - & 99 \\
\hline & NGO & 100 & - & - & \\
\hline \multirow[t]{2}{*}{ Internet } & Gov. & - & 90.8 & 9.2 & 13.5 \\
\hline & NGO & 82.4 & 5.9 & 11.7 & \\
\hline \multirow[t]{2}{*}{ Fax machines } & Gov. & - & 97.7 & 2.3 & 14.4 \\
\hline & NGO & 88.2 & 5.8 & 5.8 & \\
\hline \multirow[t]{2}{*}{ Printer } & Gov. & 97.7 & 2.3 & - & 98 \\
\hline & NGO & 100 & - & - & \\
\hline \multirow[t]{2}{*}{ Photocopier } & Gov. & 96.5 & 1.2 & 2.3 & 97.1 \\
\hline & NGO & 100 & - & - & \\
\hline \multirow[t]{2}{*}{ Office line phone } & Gov. & - & 100 & - & 16.3 \\
\hline & NGO & 100 & - & - & \\
\hline \multirow[t]{2}{*}{ Projector } & Gov & - & 88.5 & 11.5 & 16.3 \\
\hline & NGO & 100 & - & - & \\
\hline \multirow{2}{*}{$\begin{array}{r}\text { Company } \\
\text { website }\end{array}$} & Gov. & 34.5 & 43.7 & 21.8 & 45.2 \\
\hline & NGO & 100 & - & - & \\
\hline \multirow[t]{2}{*}{ Software } & Gov. & 27.6 & 48.3 & 24.1 & 39.4 \\
\hline & NGO & 100 & - & - & \\
\hline \multirow[t]{2}{*}{ Radio set } & Gov. & 13.8 & 86.2 & - & 27.9 \\
\hline & NGO & 100 & - & - & \\
\hline \multirow[t]{2}{*}{ Television set } & Gov. & 100 & - & - & 100 \\
\hline & NGO & 100 & - & - & \\
\hline \multirow{2}{*}{$\begin{array}{l}\text { Video conference } \\
\text { centre }\end{array}$} & Gov. & - & 93.1 & 6.9 & 15.4 \\
\hline & NGO & 94.1 & - & 5.9 & \\
\hline \multirow[t]{2}{*}{ E-mail use } & Gov. & 29.9 & 23 & 47.1 & 38.5 \\
\hline & NGO & 82.4 & - & 17.6 & \\
\hline \multirow[t]{2}{*}{ Web portal } & Gov. & 21.8 & 55.2 & 23 & 31.7 \\
\hline & NGO & 82.4 & - & 17.6 & \\
\hline
\end{tabular}

In Table 4 , it could also be noted that only $38.5 \%$ of the respondents indicated that they use E-mail, closely supported by $47.1 \%$ of the respondents in the public organization who consented that they had E-mail addresses and use them, with $23.0 \%$ of the respondents having no knowledge about the existence of an E-mail address in the public sector, while $82.4 \%$ of the respondents confirmed that E-mail addresses were available and $17.6 \%$ of the respondents had no idea about the presence of an E-mail address in the private sector. The results show $100 \%$ of the respondents in the private organizations confirmed the existence of software applications in their organizations. About $48.3 \%$ of the respondents in the public organizations confirmed that software was not available while $24.1 \%$ of the respondents were not able to tell the state of software as an ICT tool in their organizations.

The results in Fig. 4 demonstrate a total percentage of 13.5 of internet connectivity in the study organizations. The office line phone, one of the oldest in modern communication as well as a projector represents $16.3 \%$ each whereas development of company's website and the use of Fax Machine in these organizations represent $45.2 \%$ and $14.4 \%$ respectively. The results partially agreed with Ilomäki [27] discovery that IT is a platform where people seek information about their fields of interest, expertise, advertise their talents and works. The organizations' low interest in using the aforementioned IT tools is as a result of easy access to mobile cell phone with its associated App that could possibly use to perform almost every activity within and beyond the organization. Also, the easiest acquisition of a personal laptop is yet another contributing factor to organizations' high interest in using modem to access Internet as against the instalment of Wi-Fi router. Generally, the responses established the need for IT in management as being emphasized in a survey conducted by Rhodes and Fincham [31], they stated that the revolution based on computerised Network-information system such as email and the internet service had transformed many organizations in developed nations.

\section{USE OF IT FACILITIES}

\subsection{ICT application in the recruitment task}

In Table 5, the data indicate that workers in the study area had positive attitudes towards IT in position inventory with

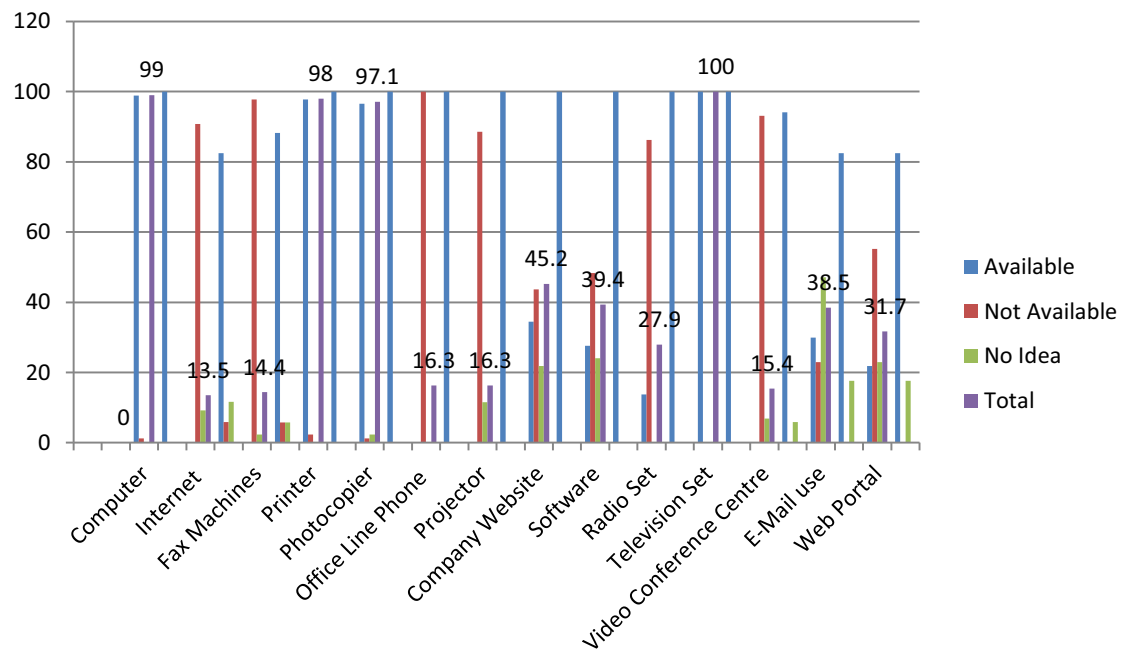

Fig. 4. Graphical presentation of availability of IT facilities in organizations 
Table 5. IT application in Human Resource Management

\begin{tabular}{|c|c|c|c|c|c|}
\hline Recruitment task & $\begin{array}{l}\text { Strongly agree. freq. } \\
\qquad(\%)\end{array}$ & $\begin{array}{l}\text { Agree. freq. } \\
\quad(\%)\end{array}$ & $\begin{array}{l}\text { Strongly disagree. freq. } \\
\qquad(\%)\end{array}$ & $\begin{array}{l}\text { Disagree. freq. } \\
(\%)\end{array}$ & $\begin{array}{c}\text { No idea freq. } \\
(\%)\end{array}$ \\
\hline Position Inventory & $51(49.0)$ & $29(27.9)$ & $2(1.9)$ & $9(8.7)$ & $13(12.5)$ \\
\hline Recruitment Using Internet & $31(29.8)$ & $27(26.0)$ & $9(8.7)$ & $25(24.0)$ & $12(11.5)$ \\
\hline Employment Selection & $38(36.5)$ & $24(23.1)$ & $8(7.7)$ & $25(24.0)$ & $9(8.7)$ \\
\hline Workforce Management & $52(50)$ & $17(16.3)$ & $8(7.7)$ & $20(19.2)$ & $7(6.7)$ \\
\hline \multicolumn{6}{|c|}{ Maintenance and Development Task } \\
\hline $\begin{array}{l}\text { Training and Human Resource } \\
\text { Development }\end{array}$ & $92(88.5)$ & $7(6.7)$ & $2(1.9)$ & $1(1.0)$ & $2(1.9)$ \\
\hline Performance Evaluation & $39(37.5)$ & $34(32.7)$ & $2(1.9)$ & $21(20.2)$ & $8(7.7)$ \\
\hline Performance Appraisal & $41(39.4)$ & $30(28.8)$ & $3(2.9)$ & $24(23.1)$ & $6(5.8)$ \\
\hline $\begin{array}{l}\text { Tardiness and Absenteeism } \\
\text { Analysis }\end{array}$ & $44(42.3)$ & $28(26.9)$ & $4(3.8)$ & $20(19.2)$ & $8(7.7)$ \\
\hline \multicolumn{6}{|l|}{ Maintenance and Planning Task } \\
\hline Personnel Files/Skills Inventory & $76(73.1)$ & $19(18.3)$ & $1(1.0)$ & $2(1.9)$ & $6(5.8)$ \\
\hline General Administration & $76(73.1)$ & $22(21.2)$ & $2(1.9)$ & $1(1.0)$ & $3(2.9)$ \\
\hline Government Reports & $55(52.9)$ & $40(38.5)$ & $4(3.8)$ & $2(1.9)$ & $3(2.9)$ \\
\hline Succession Planning & $39(37.5)$ & $42(40.4)$ & $2(1.9)$ & $10(9.6)$ & $11(10.6)$ \\
\hline
\end{tabular}

$76.9 \%$ of the respondents agreed, while $10.6 \%$ of the respondents disagreed that ICT improves position inventory and $12.5 \%$ had no idea. A total of $55.8 \%$ respondents agreed and $44.2 \%$ of the respondents either disagreed or had no idea on recruitment using internet respectively. The study shows that $40.4 \%$ of the respondents disagreed with the fact that the use of ICT for employment selection is an opportunity, however, $59.6 \%$ of the respondents agreed to the use of ICT in employment selection as a prospect to increase productivity in the work place. Also in Table 5, it could be noted that $33.7 \%$ of the total respondents disagreed to the use of ICT in workforce management. About $66.3 \%$ of the respondents agreed to ICT use in workforce management as it makes the human resource activities faster and easier. The statistics validates the conclusion that IT in management produces and stores job specification and job description records for review and redevelopment [6]. An advance in IT holds the promise of meeting the numerous challenges that face the 21st century human resource management. The IT in HR enhances its activities such as attracting, retaining and motivating employees, and meeting the demands for a more strategic human resource (HR) and administrative functions [39]. The findings, therefore, imply that regardless of the difficulty in accessing and the inadequacy of ICT facilities in most organizations, the study organizations were still making great effort to have ICT use in their recruitment task and processes.

\subsection{IT application in the maintenance and development tasks}

The data in Table 5 show $95.2 \%$ of the respondents agreed with only $4.8 \%$ of the respondents disagreed including those who could not determine using ICT in training and human resource development activities increases productivity in the human resource unit. Their responses were in consistent with the findings that employee development is expected to create a sense of certainty, enhance employability and faith in management [40]. The results confirm the statement that employees require significant training and development in IT to enable them to perform in their current jobs [17]. Furthermore, in Table 5, it reveals that $70.2 \%$ of the respondents agreed that ICT improves performance evaluation in any given organizational settings. However, those respondents that disagreed in addition to the respondents without an idea were represented by $29.8 \%$ on the assertion that ICT can improve performance evaluation. The results show that $26 \%$ of the respondents disagreed to the use of ICT in Performance Appraisal as an opportunity for organizations whereas a total of $68.2 \%$ of the respondents agreed with the fact that IT improves Performance Appraisal in organizations whilst $5.8 \%$ could not decide. Also, in Table 5, the results reveal that more than half of the respondents representing $69.2 \%$ agreed that tardiness and absenteeism analysis could easily be done faster in organizations with the aid of ICT, whereas a total respondent of $30.8 \%$ disagreed. The above findings suggest that ICT offers tools for easy and rapid performance of management and development task in the HR unit in any given organization. It affirms findings that IT applications in organizational management can reduce the cost of production, and would in the long-run increase general productivity of an organization [38].

\subsection{Information technology application in management and planning tasks}

The survey reveals that $91.4 \%$ of the respondents agreed that IT plays a vital role in improving Personnel Files and Skills Inventory while only $8.6 \%$ disagreed as being demonstrated in Table 5. In addition, the data in Table 5 show that $94.3 \%$ of the respondents agreed that IT speeds up the general administrative activities while a small number, 5.7\% disagreed with the assertion that using IT in the general administrative work makes the $\mathrm{HR}$ activities easier and faster. 
This authenticates the survey by Mishra and Akman [39] that IT can automate other routine tasks such as payroll processing, transactional activities and benefits administration. About $91.4 \%$ of the respondents were in agreement that IT improves reports generated from the HR unit and organizations to the government whereas the remaining $8.6 \%$ of the respondents disagreed, data in Table 5. The results further show in Table 5 that $77.9 \%$ of the respondents agreed that IT is a tool for successful Succession Planning and Implementation in the HRM unit, but only $22.1 \%$ of the respondents did not agree at the time of study that IT improves Succession Planning and Implementation in HR unit.

The respondents' observation perfectly agreed with the declaration that Technology is a powerful force for change and automation, and that placing IT in control of the work process is not just appealing, but also plausible and persuasive, because it allows a measure of optimism about the future of work [31]. It is also supported by Evans [6], findings of whom confirmed that Personnel Department (DP) maintains personnel records on computer, establishes databases of personnel data from which staff development programmes, retirement preparation course, manpower and needs are designed. Organizations maintaining job appraisal and salary review records have always been successful due to the deployment of IT in HR functions [6]. The findings suggest that IT helps in Management and Planning Tasks, it enables users to learn and organize complex information, recognize communication patterns, draw inferences, communicate findings and discover better organizational and problem solving skills. Also, it places emphasis on the involvement of IT in the HR activities as it leads to the fastest and easiest performance of HR tasks with potential increases in productivity.

\section{CONCLUSION}

Information Technology (IT) has become an efficient tool for virtually every activity in all sectors of nations' economies. The human resource management (HRM) functions can well be executed on the basis of the accessibility of IT coupled with satisfactory knowledge of the employee in IT and its applications. The individual employee can boast of personal ownership of some basic IT devices for domestic use, but that may not yield any positive impact on general performance of the organization. In the face of high qualification attained by individuals that are employed in these organizations, HR functions and high productivity still remain a challenge as the nonexistence of key IT devices such as video conference centre, company's website and business software to complement the effort of these talents so that they can sometime work from home as and when the need arises.

The office line phone is gradually being taken over by cell phone whereas the personal computer generally called Laptop has become a substitute for desktop computer. This has led to high demand for modem by both employers and employees so that they can have access to Internet as against the instalment of $\mathrm{Wi}-\mathrm{Fi}$ router in their organizations. It is, therefore, obvious that in less than ten years, office line phone and desktop computer will no longer be valued in the system. The incorporation of IT in HR functions has become an integral part of management since research participants in the deprived regions where the study demonstrates that the key IT facilities were unavailable at the time of survey can still envisage positive effect of IT and its application in HR functions. However, it is sad that some employees could not tell the state of Information and Communication Technology (ICT) in their organizations. Besides, the introduction of IT and its applications in HR functions can render some employees redundant. Hence, the reluctant attitudes of some organizations towards the deployment of IT in HR functions.

An organization that does not incorporate IT in its HR management often failed to introduce database management system (DBMS) to allow efficient management and data integration. DBMS minimizes isolated data, eliminates inconsistency, uncouples program-data, and increases access to available data. In addition, it enables data use, security and data centralization. The study improves the conventional (manual) method of keeping records and rendering services. More importantly, the analysis reveals that the government of Ghana achieves the Ghana ICT for Accelerated Development (ICT4AD) Policy and countries elsewhere could accomplish similar policy objective when the HR professionals and employees in various organizations are considered in the implementation stage. The advantage of IT in HR is not limited to only financial gains, but the experience in electronic-Human Resource Management (e-HRM).

For the monitoring of employees, training, development, transfers and deployment, it is recommended that the IT facilities should adequately be distributed to the HR units all over the country, because the HR unit is an engine of growth in all sectors of the Ghanaian economy. Also, the government of Ghana and countries with analogous problem must provide and mandate management and leadership in various organizations to have IT in their budgetary allocations so that they can increase the availability and utilization of IT for a higher productivity. As some organizations in deprived regions lack professionals to control IT systems and implementation in their areas of operation, the use of IT can become a policy in the Labour law that would enforce the deployment of IT systems in HR unit and the policy should constantly be amended to facilitate e-HRM in every organization. Finally, future researchers may take up similar research in the urban settings so as to ascertain a true state of Information and Communication Technology incorporation in human resource management functions within Ghana's organizational management system and strategies.

\section{REFERENCES}

[1] L. J. Mullins, Management and Organizational Behaviours, 7th ed. Harlow: Prentice Hall, 2005. 
[2] K. C. Laudon and J. P. Laudon, Management Information System: Managing the Digital Firm, 12th ed. Edinburgh, England: Pearson Education, 2003.

[3] The Republic of Ghana, "ICT4AD Policy," 2003. Retrived from http://www.moc.gov.gh/moc/PDFs/Ghana_ICT4AD_Policy.pdf7 [30/07/2020].

[4] A. Young and W. Brockbank, "Reengineering HR through information technology," J. Hum. Resource Plann., pp. 24-37, 1995.

[5] D. P. Lepak, S. A. Snell, and D. Stueber, Virtual HR Departments: Getting Out of the Middle Human Resource Management in Virtual Organizations, ICT: Information Age. London, UK: Publishing, 2002, pp. 81-101.

[6] W. D. Evans, People, Communication and Organizations, 2nd ed. Glasgow, Great Britain: Bell and Brain Ltd, 1990.

[7] J. A. O'Brien, Management Information System: A Managerial End User Perspective, 2nd ed. Chicago, United States of America: Von Hoffmann Press, 1993.

[8] Intel Teach Program, Getting Started Course, Vol. 2. USA, Intel Corporation, 2007.

[9] S. Strohmeier, "Research in e-HRM: Review and implications," Hum. Resource Manag. Rev., vol. 2007, pp. 1719-37, 2007.

[10] N. F. Wachira, Enhancing Professionalization of Human Resource Management in the Public Service in Africa, April 12-16, 2010, Cotonou, Republic of Benin.

[11] C. Andy and M. Sinan, The Effects of New Emerging Technologies on Human Resources: Emergence of Industry 4.0, a Necessary Evil. Faculty of Business and Law Department of Business Administration, University of Agder, 2017.

[12] P. Totty, "Human resources information systems," Credit Union Mag., vol. 67, no. 8, 2001.

[13] J. K. Talabi, Educational Technology: Methods, Tools, and Techniques for Effective Teaching. Kotobabi, Ghana: KOES Press, 2003.

[14] O. K. Yaw, Development in Ghana: Resource Utilization \& Challenges. Winneba-Ghana: Salt 'N' Light, 2006.

[15] S. Shrivatsava and J. B. Shaw, "Liberating HR through technology," Hum. Resource Manag., vol. 42, no. 3, pp. 201-22, 2003, 5355.

[16] M. Rahman, C. Mordi, and U. Nwagbara, "Factors influencing EHRM implementation in government organisations," J. Enterprise Inf. Manag., vol. 31, no. 2, pp. 247-75, 2018.

[17] S. Biswas, "How to develop a winning skills strategy in the fourth industrial revolution," HR Technologist, 2019, Retrieved from https://www.hrtechnologist.com/articles/digital-transformation/ how-to-develop- awinning-skills-strategy-in-the-fourthindustrial-revolution [01/07/2020].

[18] S. E. Aduwa-Ogiegbean and E. O. S. Iyamu, Using Information and Communication Technology in Secondary Schools. Nigeria, 2005.

[19] S. Ashbaugh and R. Miranda, "Technology for human resource management: Seven questions and answers," Public Personnel Manag., vol. 31, no. 1, pp. 7-20, 2002, Technology \& Society 8 (1), 104-112.

[20] S. Bawany, "What you need to lead in the industry," Hum. Resour. Online, 2018, Retrieved from https://www.humanresourcesonline. net/what-you-need-to-lead-in- theindustry-4-0 [29/06/2020].

[21] A. Tarry, The Role of HR in the 4th Industrial Revolution, UK, 2018, Retrieved from https://www.thehrdirector.com/features/ revolution/role-hr-industrial-revolution [30/07/2020].
[22] S. Booth, S. Goodman, and G. Kirkup, Gender Issues in Learning and Working with Information Technology: Social Constructs and Cultural Contexts. Hershey, United States of America: Avenue Hershey, 2010.

[23] S. Zorlu, Managing Human Resource in the 21st Century. Zorlu Senyucel \& entu Publishing, ApS, 2009, ISBN978-87-7681-468-7 bookboon.com.

[24] Y. Long, 'The impact of information technology on the HR function transformation," Unpublished Master Thesis, Business Administration HRM. University of Twente, Netherlands, March, 2009.

[25] D. Turner and P. Turner, Business Management Studies. Hong Kong, China, 1994.

[26] M. Armstrong, Armstrong's Essential Human Resource Management Practice: A Guide to People Management, 6th ed. Philadelphia, United States, 1996.

[27] L. Ilomäki, 'The effects of ICT on school: Teachers' and students' perspectives," Masters dissertation, University of Turku. Painosalama Oy-Turku, Finland, 2008.

[28] C. Caudron, "Counting heads and hiring, firing, and managing them," Profit Oracle'se- Business Mag., February, pp. 79-80, 2003.

[29] S. Pandian, "Impact of fourth industrial revolution in human resource management," Int. J. Res. Trends Innovation, pp. 59-61, 2018, Retrieved from http://www.ijrti.org/papers/IJRTI1802010. pdf [15/07/2020].

[30] E. M. Porter, Competitive Advantage: Creating and Sustaining Superior Performance. 1230 Avenue of the Americas, New York, USA, A Division of Simon \& Schuster Inc, 1985.

[31] P. Rhodes and R. Fincham, Principles of Organizational Behaviour, 3rd ed. Oxford, 1999.

[32] Softworld Report, Human Resource Management Software, Conspectus, PMP (UK) Ltd, 1997.

[33] G. Opira, "Effects of information and communication technology on students' learning," 2006/HD04/5180U, 2010.

[34] A. Wallo and H. Kock, "HR outsourcing in small and mediumsized enterprises: Exploring the role of human resource intermediaries," Personnel Rev., vol. 47, no. 5, pp. 1003-18, 2018.

[35] T. E. Adebi-Caesar, Assessment of I.C.T. situation in senior high schools: A case study in Lower ManyaKrobo District, 2012, Unpublished Master's Thesis. Kwame Nkrumah University of Science and Technology, Ghana.

[36] R. Othman and C. Teh, "On developing the formatted work place: HRM issues in Malaysia," Hum. Resource Manag. Rev., vol. 13, no. 3, pp. 393-406, 2003.

[37] T. Dunlop, "The résumé is dead: Your next click might determine your next job," 2017. Retrieved from https://www.theguardian. com/sustainablebusiness/2017/feb/16/the-resume-is- dead-yournext-click-might-determine-your-nextjob? [23/07/2020].

[38] K. Hamlin, "The advantages of outsourcing HR functions, Chron," 2019. Retrieved from https://smallbusiness.chron.com/advantagesoutsourcing-hr-functions-21169.html [06/06/2020].

[39] A. Mishra and I. Akman, "Information technology in human resource management,” Int. J. Empirical Assess., vol. 39, no. 3, 2010, Ankara, Turkey.

[40] S. S. Tzafrir, H. H. Gedaliahu, B. Yehuda, and L. D. Shimon, "The consequences of emerging HRM practices for employees 'trust in their managers," Personnel Rev., vol. 33, no. 6, pp. 628-47, 2004.

[41] C. Tansley and T. Watson, "Strategic exchange in the development of human resource information systems (HRIS)," New Technol. Work Employment, vol. 15, no. 2, pp. 108-22, 2000. 
[42] N. J. Aquilano and R. B. Chase, Production and Operation Management: Manufacturing Services, 7th ed. Chicago: Irwin, USA, 1995.
[43] R. Tubey, K. J. Rotich, and A. Kurgat, "History, evolution and development of human resource management: A Contemporary perspective," Eur. J. Business Manag., vol. VII, no. 9, pp. 139-14, 2015.

Open Access. This is an open-access article distributed under the terms of the Creative Commons Attribution-NonCommercial 4.0 International License (https:// creativecommons.org/licenses/by-nc/4.0/), which permits unrestricted use, distribution, and reproduction in any medium for non-commercial purposes, provided the original author and source are credited, a link to the CC License is provided, and changes - if any - are indicated. 